\title{
PENGARUH KONSELING KELOMPOK DENGAN PENDEKATAN TRAIT AND FACTOR TERHADAP KEMATANGAN KARIR SISWA KELAS XII SMA NEGERI 34 JAKARTA
}

\author{
Juli Sugiati ${ }^{1}$ \\ Susi Fitri ${ }^{2}$
}

\begin{abstract}
Abstrak
Kematangan karir siswa ditunjukkan oleh kemampuan siswa untuk mengukur diri, mengetahui potensi diri, penguasaan informasi jabatan atau pekerjaan, ketepatan dalam menentukan tujuan karir, kemampuan membuat perencanaan karir, dan memecahkan masalah yang mereka temui dalam berkarir dalam konteks ini adalah kemampuan memilih jurusan di pendidikan lanjut. Siswa yang menjadi sample penelitian adalah 5 orang siswa kelas XII MIPA yang dipilih menggunakan teknik purposive dengan keriteria skor kematangan karir terendah. Tujuan penelitian ini yaitu untuk mengetahui pengaruh pemberian konseling kelompok dengan pendekatan trait and factor terhadap kematangan karir peserta. Pada hasil ditemukan bahwa nilai t-hitung $-6,192$ serta nilai sig. 0,003 . Berdasarkan $\mathrm{t}$ tabel dengan $\mathrm{df}=\mathrm{n}$ $\mathrm{k}$ atau 5-2 atau t tabel 2,353 maka dengan nilai t-hitung sebesar -6,192 maka ho ditolak. Kesimpulan pada penelitian ini yaitu terdapat pengaruh penerapan konseling kelompok dengan pendekatan trait and factor terhadap kematangan karir peserta didik kelas XII SMA.
\end{abstract}

Kata Kunci: kematangan karir, konseling kelompok, trait and factor

\begin{abstract}
Student career maturity is shown by the ability of students to measure themselves, find out their potential, mastery of job or job information, accuracy in determining career goals, ability to make career planning, and solve problems they encounter in a career in this context is the ability to choose a major in further education. Students who became the study sample were 5 students of class XII Mathematics and Natural Sciences selected using purposive techniques with the lowest career maturity score criteria. The purpose of this study is to determine the effect of group counseling with the trait and factor approach to the career maturity of participants. In the results it was found that the $t$-value of $-6,192$ and sig. 0.003. Based on t table with $d f=n-k$ or 5-2 or t table 2,353 then with a t-value of -6,192 then ho is rejected. The conclusion of this study is that there is an influence of the application of group counseling with a trait and factor approach to the career maturity of high school students in class XII.

Keywords: career maturity, group counseling, trait and factor
\end{abstract}

\footnotetext{
${ }^{1}$ SMA Negeri 34 Jakarta, yulisugiati18@gmail.com

${ }^{2}$ Universitas Negeri Jakarta, susifitri@unj.ac.id
} 


\section{PENDAHULUAN}

Salah satu bagian perkembangan dari kehidupan individu yang sering mendapat perhatian tersendiri adalah masa remaja. Pada tahapan ini terdapat sejumlah tugas perkembangan yang harus dilalui oleh remaja agar menjadi seorang remaja yang matang secara usia dan mental, seperti fisik, moral, kognitif, sosial serta mempersiapkan karier. Mempersiapkan diri dalam pemilihan karier merupakan proses terhadap perkembangan individu dan prosesnya berlangsung dalam rangka menunaikan tugas-tugas perkembangan karier. Berdasarkan teori perkembangan karier, peserta didik SMA masuk kategori remaja berada pada tahap ekplorasi yang dimulai pada usia 15 sampai 24 tahun. Selanjutnya Sharf (1992) mengungkapkan tahapan eksplorasi sebagai tahap untuk mengembangkan keterampilan, minat, nilai, perencanaan masa depan, dan pada akhirnya remaja membuat keputusan. Hal ini diperkuat oleh Super (Dillard, 1985) berdasarkan teori perkembangan, masa remaja masuk kategori tahap eksplorasi pada tingkat tentatif.

Remaja seringkali memandang eksplorasi karier dan pengambilan keputusan sekolah lanjut disertai perasaan bimbang, ragu-ragu, ketidakpastian dan stress. Hal ini didukung oleh penelitian yang dilakukan oleh Triana (Setyawati, 2005) yang menunjukkan bahwa 45\% Peserta didik Sekolah Menengah Atas belum memiliki perencanaan mengenai karier yang akan dipilihnya, karena masih memiliki keraguan. Remaja mengalami kebingungan dan perasaan bimbang dengan keputusan yang akan diambil, terlihat dari sikap dan kompetensi pribadi yang minim terhadap pilihan-pilihan karier yang ada. Berdasarkan hasil studi pendahuluan melalui angket terhadap 138 Peserta didik kelas XII SMA Negeri 34 Jakarta diperoleh data sebesar 78\% Peserta didik memiliki keraguan dalam menentukan jurusan di perguruan tinggi dan masa depan mereka. Kebingungan yang sering dialami Peserta didik diantaranya pada saat mereka akan memutuskan pilihan pendidikan setelah lulus SMA, ditambah adanya perasaan cemas dalam menghadapi masa depan dan dunia kerja.

$\begin{array}{lll}\text { Salah satu bantuan yang dapat } \\ \text { diberikan } & \text { untuk menyelesaikan }\end{array}$ permasalahan karier Peserta didik SMA yaitu layanan konseling kelompok. Latipun (2001) menjelaskan bahwa konseling kelompok merupakan bantuan layanan konseling yang memanfaatkan dinamika kelompok untuk menyelesaikan permasalahan konseli. Salah satu pendekatan yang dapat digunakan untuk menyelesaikan permasalahan kematangan karier Peserta didik SMA kelas XII, yaitu pendekatan trait and factor. Manrihu (1988) menjelaskan bahwa pendekatan trait-factor memandang individu mempunyai pola sifatsifat, seperti mina, bakat, maupun cirri-ciri kepribadian yang dapat diidentifikasi melalui alat-alat obyektif berupa tes atau inventori psikologis, kemudian membuat profil kepribadian untuk menggambarkan potensi individu. Winkel dan Sri Hastuti (2006) menjelaskan bahwa pendekatan traitfactor dapat digunakan oleh konselor dalam menangani permasalahan karier Peserta didik . Peserta didik yang kurang memiliki pengalaman hidup serta kesulitan dalam membuat keputusan karier yang bijaksana mendorong konselor untuk melakukan pendekatan trait-factor.

Beberapa alasan peneliti terkait dengan perlunya konseling karier trait and factor untuk meningkatkan kematangan karier Peserta didik ditinjau dari hakekat teori trait and factor, adalah: Pertama, setiap individu memiliki seperangkat trait yang unik yang dapat diukur secara valid dan reliabel (akurat dan stabil); Kedua, bidang pekerjaan menuntut individu memiliki trait tertentu untuk mencapai keberhasilan, meskipun individu pekerja yang memiliki trait dengan rentangan dan jenis karakteristik (kemampuan) yang beragam akan menuai keberhasilan dalam pekerjaan yang tersedia; Ketiga, memilih pekerjaan adalah proses yang agak linier/langsung dan mungkin dilakukan dengan mencocokkan trait yang dimiliki individu dengan tuntutan bidang 
kerja tertentu; dan Keempat, semakin dekat hubungan (kesesuaian) antara karakteristik personal (trait) dengan tuntutan dunia kerja, akan semakin besar kemungkinan sukses kerja yang berupa produktivitas dan kepuasan kerja (productivity and satisfaction).

Penelitian ini dilakukan pada Peserta didik SMA Negeri 34 Jakarta kelas XII MIPA. Dipilih Peserta didik kelas XII karena Peserta didik kelas XII harus sudah memiliki kematangan karier sesuai dengan tugas perkembangannya.

Berangkat dari pemikiran dan fenomena yang telah dijelaskan pada latar belakang, maka rumusan masalah penelitian ini adalah "Apakah terdapat pengaruh pemberian konseling kelompok dengan pendekatan trait factor terhadap kematangan karier Peserta didik?

\section{Pengertian Kematangan Karier}

Kematangan karier adalah kesadaran akan kemampuan untuk membuat pilihan karier yang sesuai, termasuk kesadaran akan hal-hal yang dibutuhkan dalam membuat keputusan karier, serta tingkatan pilihan karier yang realistis dan konsisten sepanjang waktu (Levinson, Ohlers, Caswell, \& Kiewra, 1998).

Powell \& Luzzo memandang hal yang sama dengan Levinson dkk yakni kematangan karier merupakan suatu ukuran dari kesiapan untuk membuat keputusan karier berdasarkan sikap dan pengetahuan dari pembuatan keputusan karier (Patton \& Creed, 2001).

Kematangan karier merupakan faktor yang penting dalam perkembangan karier individu. Terlihat bahwa kematangan karier secara positif dapat meningkatkan kesadaran diri; meningkatkan pengetahuan yang berhubungan dengan pilihan, meningkatkan gambaran diri seperti kemampuan, minat, nilai dan kepribadian; meningkatkan tujuan karier; meningkatkan sikap karier seperti orientasi berprestasi, kemandirian, perencanaan, memiliki komitmen, motivasi dan efikasi diri; meningkatkan kesuksesan dan kepuasan dari perkembangan karier (Seligman, 1994).

\section{Faktor yang Mempengaruhi Kematangan Karier}

Super (Rauf, 2006) menjelaskan faktorfaktor yang mempengaruhi kematangan karier, yaitu:

a. Bio-sosial, yakni informasi yang lebih spesifik, perencanaan, penerimaan, tanggung jawab dalam perencanaan karier, mengacu pada pilihan karier yang berhubungan dengan faktor biososial seperti usia dan kecerdasan.

b. Lingkungan, yaitu indeks kematangan karier individu berhubungan positif dengan tingkat pekerjaan orang tau, kurikulum sekolah, stimulus, budaya dan kohesivitas keluarga.

c. Kepribadiaan, meliputi konsep diri fokur kendali, bakat khusus, nilai atau norma-norma dan tujuan hidup

d. Vokasional, kematangan karier individu berhubungan positif dengan aspira vokasional, tingkat kesesuaian aspira dan ekspektasi karier.

e. Prestasi individu, mencakup aspek akademik, kebebasan, partisipasi dalam kegiatan intra kurikuler maupun ekstra kurikuler.

\section{PENDEKATAN \\ TRAIT FACTOR \\ Konsep teori Trait-Factor}

Menurut Parson (Sharf, 2013), untuk memilih karier hendaknya seorang individu idealnya harus memiliki:

a. Pengertian yang jelas mengenai diri sendiri, sikap, minat, ambisi, batasan sumber dan akibatnya

b. Pengetahuan akan syarat-syarat dari kondisi sukses, keuntungan dan kerugian, kompensasi, kesempatan dan harapan masa depan pada jenis pekerjaan yang berbeda-beda.

c. Pemikiran yang nyata mengenai hubungan antara dua kelompok atau fakta-fakta ini. 
Menurut pandangan Parson dan Williamson (Winkel \& Hastuti, 2006) ciri khas dari teori trait and factor ialah bahwa seseorang dapat menemukan vocasional yang cocok baginya dengan mengkorelasikan kemampuan, potensi, dan wujud minat yang dimilikinya dengan kualitas-kualitas yang secara objektif dituntut bila akan memegang vokasional tertentu. Pandangan ini bagaimaa individu membuat pilihan karier yang dapat dipertanggung jawabkan. Kemampuan minat individu ini dapat diketahui melalui testing.

Pada dasarnya teori trait and factor menyatakan bahwa pemilihan karier individu sangat ditentukan oleh kesesuaian kemampuan (abilities), minat (interest), prestasi (achievement), nilai-nilai (value) dan kepribadian (personality) dengan dunia kerja (word of work). Bila digambarkan sebagai berikut:

\section{Matching}

Self Word of Work

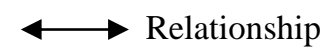

\section{Model Konseling kelompok dengan pendekatan trait factor}

Konseling kelompok dengan pendekatan trait and factor dapat dikatakan efektif untuk membantu meningkatkan kematangan karier siswa, seperti penelitian yang dilakukan oleh Erlinda (2016) yang berjudul "Keefektifan Model Konseling Trait And Factor Untuk Meningkatkan Kemampuan Pengambilan Keputusan Karier Siswa Kelas XII Di Sma Negeri 5 Banjarmasin Denta (2015) yang berjudul "Penerapan Konseling Kelompok Model Trait and Factor untuk Meningkatkan Kemantapan Pilihan Karier Siswa kelas XII" yang bertujuan mengetahui pengambilan keputusan karir siswa kelas XII SMA Negeri 5 Banjarmasin sebelum dan sesudah diberikan model konseling trai and factor dalam program layanan konseling kelompok, serta untuk mengetahui efektivitas model konseling ini dalam meningkatkan pengambilan keputusan karir siswa kelas XII SMA Negeri 5 Banjarmasin.
Hasil dari penelitian ada perbedaan tingkat pengambilan keputusan karir siswa sebelum diberikan konseling dengan menggunakan model konseling trait and factor dan sesudah diberikan konseling.

Hasil penelitian lain yang dilakukan Denta (2015) yang berjudul "Penerapan Konseling Kelompok Model Trait and Factor untuk Meningkatkan Kemantapan Pilihan Karier Siswa kelas XI Kompetensi keahlian 4 Akutansi SMK Negeri 10 Surabaya" yang bertujuan untuk mengetahui perbedaan dalam kemantapan pilihan karier antara sebelum dan sesudah pemberian konseling kelompok trait and factor pada Siswa kelas XI Kopetensi keahlian Akutansi SMK Negeri 10 Surabaya kepada 33 siswa. Hasil dari penelitian yang dilakukan menunjukkan adanya peningkatan kemantapan pilihan karier antara sebelum dan sesudah pemberian perlakuan berupa konseling kelompok trait and factor.

Berdasarkan hasil penelitian tersebut diatas dapat disimpulkan bahwa konseling kelompok dengan pendekatan trait and factor merupakan model yang tepat untuk membantu meningkatkan kematangan karier siswa.

\section{METODE PENELITIAN}

Penelitian ini bertujuan untuk melihat pengaruh konseling kelompok dengan pendekatan trait-factor terhadap kematangan karier Peserta didik SMA Negeri 34 Jakarta. Penelitian ini dilakukan pada bulan Januari hingga Agustus 2018 yang dimulai dari tahap persiapan, pelaksanaan dan pelaporan yang bertempat di SMA Negeri 34 yang beralamat Jl. Margasatwa Raya No. 1, Pondok Labu, Cilandak, Jakarta Selatan. Metode penelitian yang digunakan dalam penelitian adalah metode eksperimen . Metode eksperimen adalah metode yang digunakan untuk mencari pengaruh perlakuan tertentu terhadap yang lain dalam kondisi yang terkendalikan (Sugiyono, 2009).

Jenis penelitian eksperimen adalah pra eksperimental (Sugiyono, 2009) Metode 
penelitian yang digunakan adalah pra eksperimen dengan the one pretest-posttest design. Penelitian ini melibatkan satu kelompok yang diberikan perlakuan dengan dilakukan pengukuran pada pretest dan posttest.

Populasi dalam penelitian ini adalah seluruh Peserta didik kelas XII MIPA, SMA Negeri 34 Jakarta yang berjumlah 108 orang. Teknik pengambilan sampel yang digunakan untuk memilih subyek penelitian adalah teknik Purposive Sampling atau sampel bertujuan. Purposive sampling yaitu teknik sampling yang didasarkan atas adanya tujuan tertentu. Teknik ini biasa dilakukan karena beberapa pertimbangan yang disesuaikan dengan tujuan penelitian. (Arikunto, 2010).

Uji validitas yang dilakukan dengan mengukur koefisien korelasi skor item setiap butir dengan skor total. Rumus validitas yang digunakan dalam instrument ini adalah korelasi Pearson Product-moment dengan bantuan aplikasi Statistical Product and Service Solution (SPSS) 19. Setelah dilakukan uji validitas, dari 85 butir yang diujikan, 76 butir pernyataan dinyatakan valid dan 9 lainnya dinyatakan tidak valid.

\section{HASIL PENELITIAN}

Berdasarkan pengukuran pretest terhadap populasi penulisan yaitu sebanyak 92 Peserta didik kelas XII MIPA tahun pelajaran 2018-2019, terdapat 40 Peserta didik termasuk kategori sangat rendah dan rendah kematangan kariernya. Dari 40 orang sampling, dipilih 10 orang secara acak sebagai sampel penulisan. Dari 10 orang terbagi kedalam 2 kelompok, diambil dengan cara dikocok, yaitu 5 orang kelompok eksperimen dan 5 orang pada kelompok kontrol, dengan hasil sebagai berikut: (nama yang digunakan menggunakan inisial).
Tabel 1.

Skor Pretest kelompok Eksperimen dan Kelompok Kontrol

\begin{tabular}{|c|c|c|c|c|c|c|c|c|c|}
\hline \multicolumn{5}{|c|}{ Kelompok Eksperimen } & \multicolumn{5}{|c|}{ Kelompok Kontrol } \\
\hline No & Inisial & Kelas & Skor & Kategori & No & Inisial & Kelas & Skor & Kategori \\
\hline 1 & DAF & MIPA-3 & 210 & Kurang & 1 & APH & MIPA-3 & 215 & Kurang \\
\hline 2 & HAN & MIPA-1 & 207 & Sangat Kurang & 2 & $\mathrm{HCH}$ & MIPA-1 & 226 & Kurang \\
\hline 3 & MON & MIPA-1 & 205 & Sangat Kurang & 3 & INA & MIPA-1 & 223 & Kurang \\
\hline 4 & NAD & MIPA-1 & 218 & Kurang & 4 & RAR & MIPA-3 & 205 & Sangat Kurang \\
\hline 5 & VEN & MIPA-1 & 219 & Kurang & 5 & $\mathrm{ZAH}$ & MIPA-1 & 216 & Kurang \\
\hline \multicolumn{3}{|c|}{ ¿Eksperimen: } & 1059 & $\dot{\mathrm{X}}=211,8$ & \multicolumn{3}{|c|}{$\sum$ kontrol $=$} & 1085 & $\dot{X}=217$ \\
\hline
\end{tabular}

Berdasarkan data diketahui bahwa terdapat perbedaan skor antara kelompok eksperimen dan kelompok kontrol, yaitu sebesar 26 poin dimana kelompok kontrol memiliki skor lebih tinggi dibandingkan kelompok eksperimen dan selisih rata-rata sebesar 5,2, dimana kelompok kontrol lebih tinggi perolehan rata-ratanya dibandingkan kelompok eksperimen.

Setelah dilakukan pretest maka langkah selanjutnya adalah kelompok eksperimen diberikan treatment konseling kelompok trait and factor sebanyak 10 kali pertemuan, sedangkan kelompok kontrol tidak diberikan treatment.

Topik yang disusun dalam kegiatan konseling kelompok berdasarkan pada permasalahan Peserta didik yang memiliki kematangan karier kategori sangat kurang dan kurang.

Kematangan karir siswa sangat dipengaruhi oleh kemampuan siswa dalam mengambil keputusan. Seorang siswa harus mengetahui apa yang harus dipertimbangkan dalam membuat pilihan pendidikan dan karier, kemudian membuat pilihan studi lanjut dan pekerjaan yang sesuai dengan minat dan kemampuan. Pada aspek keputusan karir berdasarkan hasil analisa indikator siswa masih kurang pada:

a. Belum mengetahui langkah-langkah apa yang akan dilakukan untuk memutuskan studi lanjut kelak

b. Belum dapat memutuskan sendiri dan juga tidak bertanya kepada teman alasannya memilih perguruan tinggi yang diinginkan setelah lulus SMA 
c. Kurang membaca biografi orang sukses dalam pendidikan atau buku tentang strategi mencapai sukses

Aspek kematangan karir pada komponen pengetahuan atau informasi dunia kerja berdasarkan analisa adalah siswa belum memahamai tuntutan dunia kerja terhadap bidang kariernya. Pada aspek ini siswa perlu banyak mencari tahu bidangbidang pekerjaan dan persyaratan yang dibutuhkan.

Berdasarkan hasil wawancara kepada siswa yang memiliki kematangan karir kategori kurang sampai dengan sangat kurang dapat disimpulkan kelompok siswa tersebut memiliki keraguan atau bahkan tidak memiliki pilihan dalam memilih jurusan dan karir di masa depan. Hal ini disebabkan sejak SMP mereka sudah harus memilih karir awal yaitu, memilih peminatan MIPA, IPS, maupun bahasa. Sejalan dengan pendapat Santrock (2011) menyatakan bahwa remaja sering menganggap eksplorasi karier dan pengambilan keputusan disertai dengan perasaan bimbang, ragu-ragu, ketidakpastian dan stress. Untuk itu siswa memerlukan bantuan.

Setelah diberikan konseling trait and factor diperoleh hasil post test berdasarkan tabel di bawah ini :

Tabel 2

Hasil Pretest dan Posttest Kematangan Karir siswa

\begin{tabular}{|c|c|c|c|c|c|}
\hline \multicolumn{6}{|c|}{ Kelompok Eksperimen } \\
\hline Nama & Kelas & $\begin{array}{l}\text { Skor } \\
\text { Pretest }\end{array}$ & Kategori & $\begin{array}{l}\text { Skor } \\
\text { Post } \\
\text { test }\end{array}$ & Kategori \\
\hline DAF & MIPA-3 & 210 & Kurang & 279 & Tinggi \\
\hline HAN & MIPA-1 & 207 & $\begin{array}{l}\text { Sangat } \\
\text { Kurang }\end{array}$ & 265 & Sedang \\
\hline MON & MIPA-1 & 205 & $\begin{array}{l}\text { Sangat } \\
\text { Kurang }\end{array}$ & 278 & Tinggi \\
\hline NAD & MIPA-1 & 218 & Kurang & 276 & Tinggi \\
\hline VEN & MIPA-1 & 219 & Kurang & 297 & $\begin{array}{l}\text { Sangat } \\
\text { Tinggi }\end{array}$ \\
\hline
\end{tabular}

Berdasarkan hasil uji statistik dengan menggunakan wilcoxon match pairs test, terjadi perubahan yang bersifat positif, artinya terjadi peningkatan skor pada posttest yang telah dilakukan. Selanjutnya, hasil uji statistik juga menunjukan nilai signifikansi sebesar 0,003 (lebih kecil dari signifikasi $\alpha 0.05$ ).

Hal ini dapat terjadi karena siswa diberikan bantuan dengan konseling kelompok pendekatan trait-factor. Pendekatan trait factor awalnya merupakan konseling karir yang bertujuan membantu individu yang mengalami kecemasan dalam pemilihan karir. Individu yang memiliki kecemasan karir biasanya disebabkan karena siswa yang bersangkutan belum melakukan analisis diri, yang mencakup kemampuan mengidentifikasi bakat minat yang dapat diukur secara valid melalui tes psikologi (Manrihu, 1988).

Menurut Parson dan Williamson (Winkel \& Hastuti, 2006) menyatakan bahwa pemilihan karier individu sangat ditentukan oleh kesesuaian kemampuan, minat, prestasi, nilai-nilai dan kepribadian dengan dunia kerja, sehingga individu tersebut dapat mencapai kematangan karier.

Konseling dilakukan secara kelompok dirasakan efektif karena siswa SMA senang berkelompok dengan teman sebaya sehingga mereka dapat melaksanakan aktivitas secara bersama.

\section{KESIMPULAN}

Setelah semua tahapan dalam penelitian dilakukan, merujuk dari hasil penelitian, dapat disimpulkan secara umum bahwa konseling kelompok dengan pendekatan trait and factor dapat meningkatkan kematangan karier Peserta didik. Secara khusus dapat disimpulkan hasil penelitian adalah sebagai berikut:

a. Konseling kelompok dengan pendekatan trait-factor memberikan pengaruh terhadap peningkatan kematangan karier Peserta didik dan bertambah secara signifikan setelah diberikan konseling trait factor. Perubahan terjadi pada semua aspek kematangan karier. Perubahan terbesar pada aspek perencanaan karier dan eksplorasi karier. 
b. Aktivitas yang dilakukan secara kelompok terbukti dapat menambah wawasan mereka tentang karier sehingga antar anggota kelompok dapat saling membantu mengesplorasi diri dan prasyarat karier yang dibutukan.

\section{DAFTAR PUSTAKA}

Arikunto, S. (2010). Prosedur Penelitian: Suatu Pendekatan Praktik. Jakarta: Rineka Cipta.

Dillard, J. M. (1985). Lifelong career planning. Columbus: C.E. Merrill.

Erlinda, C., Sulistiyana, Permatasari, N., \& Rachmayanie, R. (2016). Keefektifan model konseling trait and factor untuk meningkatkan kemampuan pengambilan keputusan karier siswa kelas XI di SMA Negeri 5 Banjarmasin. Jurnal Bimbingan Dan Konseling Fitrah, 1(1), 25-36.

Latipun. (2001). Psikologi Konseling. Malang: UMM Press.

Levinson, E. M., Ohlers, D. L., Caswell, S., \& Kiewra, K. (1998). Six Approaches to the Assessment of Career Maturity. Journal of Counseling \& Development, 76(4), 475-482. https://doi.org/10.1002/j.15566676.1998.tb02707.x

Manrihu, M. T. (1988). Pengantar Bimbingan dan Konseling Karir. Jakarta: Departemen Pendidikan dan Kebudayaan.

Patton, W., \& Creed, P. A. (2001). Developmental Issues in Career Maturity and Career Decision Status. The Career Development Quarterly, 49(4), 336-351. https://doi.org/10.1002/j.21610045.2001.tb00961.x

Santrock, J. W. (2011). Life Span Development (5th ed.). Jakarta: Erlangga.

Seligman, L. (1994). Developmental career counseling and assessment (2nd ed.). Thousand Oaks, CA, US: Sage Publications, Inc.
Setyawati, C. L. (. (2005). Sikap siswa terhadap layanan bimbingan karier di SMA Tarsisius Vireta Tangerang. Jurnal Psikoedukasi, 3(2), 112-127.

Sharf, R. S. (1992). Applying career development theory to counseling. Applying Career Development Theory to Counseling. California: Woodswoth.

Sharf, R. S. (2013). Applying Career Development Theory to Counseling (6th ed.). Boston: Thomas Brooks/Cole.

Sugiyono. (2009). Metode Penelitian Kuantitatif, Kualitatif, dan $R \& D$. Bandung: Alfabeta.

Winkel, W., \& Hastuti, S. (2006). Bimbingan dan Konseling di Institusi Pendidikan. Jakarta: Grasindo. 